\title{
If Love Was a Crime, We Would Be Criminals: the Eurovision Song Contest and the Queer International Politics of Flags \\ Catherine Baker
}

The flag is a basic unit of meaning in the grammar of international politics. Flags on their own symbolise individual states and nations, standing as a visual shorthand for the group of people who make up the nation and for the territory they are connected to, as well as the institution that exercises national sovereignty within defined territorial borders which we call 'the state'. Flags gathered together visualise the very idea of why international politics are 'international': inside a sports arena or outside an international organisation's headquarters, they symbolise the principle that the community formed there consists of distinct nations and sovereign states (Saugmann Andersen, Guillaume and Vuori 2016: 137). The taken-for-granted place that national flags have in everyday life for most people famously led the sociologist Michael Billig (1995) to call flags one of the most powerful instruments of 'banal nationalism': in the contemporary world we are so used to seeing flags hanging over public buildings, given pride of place at ceremonial occasions, or displayed in stadiums, shops, windows and cars during international competitions, or decorating the scoreboard of the Eurovision Song Contest, that we rarely question why nationhood, rather than any other principle, delimits political authority over territory around the world.

Eurovision, which shares much of its logic with international sports 'mega-events' and since the 1990s has increasingly come to resemble them organisationally (Bölin 2006: 197), relies on flags just as much as the Olympic Games do to create its live and broadcast atmosphere. Yet flags are at their most revealing when they are contested: that is, when their meanings or legitimacy are disputed. The politics of recognition in which flags operate means that disputes about flags are not just disputes about a coloured symbol on screen or a piece of cloth: they are disputes about the legitimacy of the group that the flag represents, that is, whether the nation or other collective represented by the flag has the right to belong in the space that the flag might be admitted to or excluded from. In 2015-16, a series of controversies about the display of flags during Eurovision broadcasts brought the international politics of flags into the foreground. Yet these controversies did not just involve national flags but also pride flags - that is, flags representing a sexuality or a way of embodying gender around which activists have created collective communities, which in some ways resemble nations and in other ways confound logics of nationalism.

Flags become contentious at Eurovision when they encroach on another structuring principle of the competition, the determination of the European Broadcasting Union (EBU) to make the contest it organises a supposedly non-political space. Eurovision's rules prohibit 'lyrics, speeches [and] gestures of a political, commercial or similar nature', and also prevent 'messages promoting any organization, institution, political cause or other company, brand, products or services' across all the host city's Eurovision venues (EBU 2019). This protects the contest and its sponsors from 'ambush marketing', but also constrains performers making it 
a platform for activism (the 2017 Portuguese contestant Salvador Sobral, for instance, wore an 'SOS Refugees' sweatshirt to some press conferences until the EBU asked him to stop the day before the grand final (Honciuc 2017)). And yet the boundaries of what is and is not political are regularly tested when broadcasters choose songs with historical, social, economic or environmental themes (the French entry in 2018 commemorated the refugee rescue boat SOS Aquarius; Swedish Television (SVT) incorporated a sombre reflection on the refugee crisis into one 2016 semi-final when it commissioned an interpretive dance act, 'The Grey People', for the interval).

In practice, the rule unambiguously catches references to political leaders, with Ukraine's 2005 host entry (an Orange Revolution anthem) having to remove lines about President Viktor Yushchenko, and Georgia's 2009 entry, after the 2008 Russian-Georgian War, being disqualified altogether for its title's thinly-veiled pun, 'We Don't Wanna Put In'. Commemorations of genocide and mass violence, meanwhile, have been allowed (Ukraine's 2016 winning entry, '1944', commemorated Stalin's deportation of the Crimean Tatars while clearly paralleling Russia's annexation of Crimea; Armenia's 2015 entry 'Face the Shadow', marking the centenary of the Armenian Genocide, was originally titled 'Don't Deny' (Fornäs 2017: 188) even though they can be the subject of divided memories between different competitor states. Here, the EBU is in a similar position to the International Federation of Association Football (FIFA) when asked to determine whether British remembrance poppies are unacceptably 'political' on national teams' shirts (see Åhäll 2018): commemorations which have been normalised and made to seem non-political in one nation may be contentious or directly clashing in another member nation which the organisation ought to treat equally. Moreover, the process of making songs 'political' does not stop with creators or organisers: viewers too can project political meanings on to songs using their contextual knowledge, such as hearing the chorus of Poli Genova's 2016 Bulgarian entry ('If love was a crime, we would be criminals') as 'lyrics [...] aimed at Russia's anti-gay laws' (Hart 2017). These ambiguities in determining whether or not something is 'political' apply not just to songs but also to flags. Examining those flags that could count on support when challenged and those that could not exposes struggles over how the EBU, local organisers, and fans understood the boundaries of what is 'political' in international competition, and reveals that Eurovision's supposedly transnational public sphere was still on a deeper level structured around nationstates.

\section{National flags and pride flags in international politics}

The history of the flag in international politics is, in fact, the history of nationalism itself. Mapping dynastic regimes' denoting of ownership through flags and emblems on to the principle of popular sovereignty, national movements from the French, American and Haitian Revolutions onwards created flags that signalled a break from the old regime, and/or revived past kingdoms' and rulers' flags as evidence of their nation's historical longevity and right to sovereignty (Hobsbawm 1983: 11-12). Among the ways of binding people into national communities that one might call 'technologies of nationalism' (Confino and Skaria 2002: 8), 
flags have a ceremonial and ritual significance which can amount to sanctity, and are ubiquitous enough to seem normal in everyday life (Yuval-Davis and Stoetzler 2002: 334). They can simultaneously signal exclusion rather than inclusion to ethnic, racial and sexual minorities whose right to belong in the nation has been made insecure (Ahmed 2004: 130). Internationally, flags make the nation distinguishable from others, and even before 'nationbranding' became a commercial art in the 1990s-2000s (with Eurovision a major vehicle for it (Jordan 2014)), certain nations' flags were among the world's most powerful brand images (Jansen 2008: 122). Flags are, as Eric Hobsbawm (1992: 72) wrote, 'the universal [...] symbol of modern nations', even more so than that other technology of nationalism, the anthem (see Kelen 2014): some nations (including England) have existed as cultural and political communities for centuries without an officially-defined anthem, but it is hard to imagine a contemporary nation even being taken seriously if it declared itself without proclaiming a flag.

National flags are not, however, the only flags that matter in international politics - or in Eurovision. Other bodies and collectives also use flags to denote their own identities, visualise their identities using the same forms of graphical communication and design as national flags, and inspire the sentiments of loyalty, identification and belonging that nationhood is thought to evoke - or rather, people and organisations design and display flags hoping the community they are addressing will take them up. One clearly significant set of flags in international politics belong to international organisations. The 'European flag' with twelve gold stars on a blue background, adopted by the Council of Europe (COE) in 1955 and the European Parliament in 1983, became the official flag of the then European Community (EC) in 1985, with both institutional and symbolic meanings (even though the common notion that its twelve stars match the EC's twelve member states in 1985 is a mistaken analogy with the US flag: the CoE chose twelve stars 'to signify perfection and harmony' (Fornäs 2012: 118)). Today's European Union (EU) describes the flag as standing for the EU and 'more broadly, the identity and unity of Europe' (European Union 2019). Twelve bright stars on a dark blue background were also the logo of the EBU's 'Eurovision Network' until 1993 (Vuletic 2018: 150). The 'European' flag's iconicity could well persuade viewers noticing the old Eurovision logo that the EBU and EU were connected. The EU has certainly done much to associate the flag with wider notions of 'European culture' (Kaelberer 2004: 170). But the relationship between the two organisations and the EU flag is more complicated: as Dean Vuletic (2018: 32-3) shows, the EBU selected the twelve-star logo first, adopting it for the Eurovision Network one year before the CoE. The British Broadcasting Corporation (BBC) designer who created the Eurovision Network logo had apparently been inspired by CoE proposals. Once the EC/EU started identifying the European flag with European political integration (on which the governments of EBU members had very different stances), however, the EBU stepped away from it: its 1993 logo with three V-shaped brush-strokes in different blue colours around a gold ring resisted identification with the EU project even as Eurovision, bringing in former state socialist countries, was starting an enlargement of its own.

Another category of flag in international politics, the pride flag, has been propagated by activists seeking to signify communities with a common culture and heritage, a demand for 
recognition and a need for emancipation, but defined by sexual and gender-variant identities rather than national or ethnic belonging. The original Pride flag, with horizontal stripes in rainbow colours, was created in 1978 by the San Francisco artist Gilbert Baker and by the mid1990s had overtaken the pink triangle of gay liberation (a reclamation of the symbol forced on homosexual prisoners in Nazi concentration camps) as an international symbol of the LGBTQ rights movement (Chinn 2012: 124). Since the late 1990s, designers seeking greater recognition for specific sexual orientations or relationships to gender identity - especially identities that cisgender (non-transgender) gay and lesbian activism had marginalised - have adapted the rainbow flag's visual grammar by using horizontal fields of colour in combinations that often connote a message about the identity they represent, e.g. by playing on the gendered meanings of blue and pink. The bisexual pride flag, designed by a bi US man, Michael Page, in 1998, uses pink, lavender and blue bands in a 2:1:2 ratio to suggest attraction to multiple genders but also the ways that bi people blend invisibly (not necessarily by choice) into queer and straight social worlds (Madison 2018: 150-1). The trans pride flag, with bands of light blue, pink, white, pink and light blue, was designed in 1999 by a trans woman and US Navy veteran, Monica Helms (Ramirez and Sterzing 2017: 72). Queer activists of colour have meanwhile added black and brown stripes to the rainbow flag to symbolise commitment to fighting for queer liberation and racial justice at once (Klapeer and Laskar 2018: 536). These innovations, and the very idea of the pride flag, are North American, but since the 1990s have circulated transnationally through digital queer cultures, which have often borrowed language and iconography from Anglophone movements, making other pride flags besides the rainbow flag increasingly common sights at European Prides (and elsewhere).

Pride flags, especially the rainbow flag, have thus become significant symbols in international politics themselves. Activist movements have used them to demand equal rights from states and to protest against police repression, using massed flags' visual spectacle to stake a symbolic claim for visibility (Ammaturo 2016); advertisers and tourist boards have used the rainbow flag in marketing to those LGBTQ travellers they believe have high disposable income, especially middle-class gay men (Bell and Binnie 2004); in the 2000s when the EU expected accession candidates' governments to allow and secure Pride marches as evidence they were making the necessary progress on human rights, photographs of wellattended Pride marches with many rainbow flags became a quick visual shorthand for how well they were doing (see Bilić 2016). Anti-LGBTQ movements and regimes, too, have recognised the rainbow flag as identity symbol and political claim, and the Russian parliament's controversial law in 2013 against promoting 'non-traditional sexual relations' (that is, diverse sexualities and gender non-conformity) to under-18s - a move with immediate repercussions for the politics of Eurovision (Baker 2017: 107-10) - extends in police practice to the rainbow flag (Suchland 2018: 2). States in the late 2000s and 2010s wishing to suggest their nation stood out from others in its progress on LGBTQ rights lit up state buildings in rainbow colours, flew them over diplomatic missions, let LGBTQ troops march under it at Pride, and (in 2017-18 Sweden) even used it in advertising to suggest sexual freedom and gender diversity were part of what the national military existed to defend 
(Strand and Kehl 2018). As the rainbow flag and other pride flags have rippled out from the US to become 'a visible manifestation of transnational ways of queer being [...] and belonging' (Klapeer and Laskar 2018: 524), they have simultaneously become contentious political symbols.

National, international and pride flags, and their colours, are all therefore politicised objects in international relations. All purport to represent a community of people with a collective identity based on shared culture, history and heritage - the 'common myths and memories' (Smith 1991: 40) which must be reproduced and reperformed to sustain national identity. The logic of the pride flag translates this mode of symbolic collective identification on to a community which does not perpetuate itself through biological reproduction (rather, its members must find out about and join the community anew every generation) and does not claim state-like sovereignty over territory - though it often ties itself to small autonomous spaces it has had to defend against surveillance, moralising and violence from the state. In this respect, pride flags queer the concept of the nation. Yet what all three forms of flags have in common is that they exist in a field of struggle about whether the groups they refer to have the right to be represented in the spaces they have entered - that is, whether the identity and political community they stand for is going to be recognised.

Flags, in fact, raise questions of recognition on two levels. Newer pride flags can suffer from a literal problem of recognition in that their associations are not as widely known as the rainbow flag, even to some individuals they might hail, let alone the wider public (Hartman 2013: 51). Flags of small states, or states whose flags are easily confused (an endemic difficulty for Slovakia and Slovenia, in Eurovision and elsewhere (Bajt 2017: 28)), suffer a similar recognition problem. On a deeper level, flags in international politics are the subjects of struggles about political recognition: whether the entities and communities they represent have fulfilled the criteria for acceptance into the 'world of nations' (Billig 1995: 6) on the same terms as those which have already been confirmed to belong. Though international law lays down criteria for statehood, the foreign policy of other governments and international organisations determines how they apply these criteria to entities demanding recognition as states (Caspersen 2015: 393). Such negotiations can even involve struggles over flags themselves: the peace implementation process in Bosnia-Herzegovina and the preindependence process in Kosovo left both countries with flags based on the EU flag's iconography, avoiding historic symbols that could imply a certain ethnic group could claim the country as its nation-state (Kolst $\varnothing$ 2006: 680-5; Obućina 2011: 35). In theoretical terms, the legitimacy of a state in search of recognition is produced between the entity which claims it and the other states and bodies which accept or reject their claim - as is the legitimacy of LGBTQ minorities' claims to be 'rights-bearing subjects' in Western liberal democratic logic (Sabsay 2016: 102). The intersubjective nature of identity and identification, where '[i]dentities [...] are acquired, claimed and allocated within power relations' (Jenkins 2014: 47) through identity claims and through reactions to them, therefore does not just explain the social identities of individuals - it also explains the international social identities of nations 
and states. This was exemplified by several linked struggles over flags at Eurovision in 2015 and 2016.

\section{Eurovision and the backstage politics of flags}

Eurovision, like the sports tournaments Michael Billig (1995) describes, is structured on a logic of 'banal nationalism', where much of the meaning and pleasure spectators make from its performances comes from the spectacle of nation competing against nation. Whether a Eurovision entry performs a globalised and 'Western' popular music genre or showcases music, dance, language or costume that it offers up as national tradition, the structure of Eurovision invites the audience to understand that that nation is accomplished in them; even entries that remediate national folklore simultaneously convey the subject position of a 'selfexoticising' entrepreneur adapting to what the Western/European gaze expects of their peripheralised nation (see Baker 2008). Indeed, Eurovision 2016 famously parodied this dynamic in Måns Zelmerlöw and Petra Mede's interval act, 'Love Love Peace Peace'.

Semiotically, the international competitive structure of Eurovision invites a spectatorial 'gaze' (or way of seeing) in which all performers embody their nations, and their embodied performances draw meaning from how they harness or subvert audience expectations about gender, nation, ethnicity, sexuality and race (see Kestnbaum 1993). The logic of performers embodying their nations is most concrete when performers wear outfits purporting to be national folk costumes (whether to claim authenticity, as when six grandmothers from the Udmurt folk ensemble Buranovskiye Babushki represented Russia in 2012, or to be ostensibly parodic, as with the female dancers supporting Donatan and Cleo's 'My Stowanie (We Are Slavic)' for Poland in 2014), but also encompasses a much wider range of recognisably 'national' masculinities and femininities: most recent male Italian entrants, for instance, have worn sharp retro-styled suits and haircuts harking back to the iconic Italian men's fashion of the 1950s and 1960s. Because much Eurovision research is devoted to critical analysis of performances and broadcasts, the aspect of embodied performance is probably the domain through which Eurovision's structuring logic of nationalism has been most researched (see, e.g., Sieg 2013). Yet its backstage politics and economics also deserve attention, and among these are the politics of flags.

The backstage politics of flags at Eurovision are, of course, to do with which flags, in which ways, should (not) be on the broadcast that constitutes Eurovision's expanded stage. Symbolically, flags denote people, objects and places as belonging to the nation they represent (Kolstø 2006), so it is logical that Eurovision's visual culture makes them play many roles. Besides references to national flags designed into some individual performances, flags have been built into the ritual structure of Eurovision through on-screen banners when telephone voting numbers are displayed, and through the convention of the 'postcard' (Bohlman 2013: 35-6). These clips, filmed either in the host country or performers' own countries, are vignettes of national and local culture and typically end on an image reworking symbols and colours from performers' national flags. Eurovision winners echo athletic victory laps by taking their national flags on stage, and in 1999 (recognising the Kosovo War, which 
was then taking place) all the contestants in the Jerusalem contest reunited on stage after the victor's reprise to wave their national flags and sing Israel's famous Eurovision winner 'Hallelujah' as a performance of peace. Green-room sequences are filled with flags held by performers and fellow delegation members when the camera pans past (Lam 2018: 121). When SVT organised Eurovision 2013 in Malmö, one of several innovations it appeared to borrow from the London 2012 Olympics was beginning the grand final with a flag parade where the contestants crossed the arena in performance order carrying their national flags. This provided the same kind of 'democratising' contrast to the heavily-criticised 2012 Baku contest (see Gluhovic 2013) that the 2012 Olympic opening ceremony had drawn between London and 2008's 'authoritarian' Beijing. Subsequent grand finals have retained the opening flag parade, writing it into Eurovision ritual. The heart-shaped Eurovision logo introduced in 2004, meanwhile, was designed to be fillable with every competitor's flag, tying flags into the economics of Eurovision by permitting the commercial and amateur manufacture of nationally-branded merchandise.

These appearances of flags on screen are almost entirely uncontested: they are within the ritual structure or permitted by it, and as competitors' flags they necessarily belong to countries whose presence is unchallenged within Eurovision's society of states. Historically, broadcasters could only compete in Eurovision once their states had gained international recognition and they had become full EBU members (Australia's participation since 2015 involves a special arrangement based on its Special Broadcasting Service (SBS) being an associate member). But this consensus has had to be created by rejecting prospective members that do not recognise all Eurovision's existing states, and the EBU has been firm that countries that ban Israeli content - like Lebanon, where the broadcaster Téle Liban got as far as selecting a song for Eurovision 2005 - will not be admitted (Raykoff 2007: 2). Yet the EBU is not the only actor responsible for the display of flags at Eurovision. Delegations bring their own flags into the green room, and as stage props: in 2000, the Israeli Broadcasting Authority (IBA) withdrew sponsorship from the band Ping Pong after they waved Syrian and Israeli flags on stage (Bohlman and Rehding 2013: 288), in a much less institutionally sanctioned peace demonstration than the staging of 'Hallelujah' in 1999. An even greater mass of flags fills the arena in live broadcasts through the agency of fans.

The practical politics of flags, Thomas Hylland Eriksen argues, are a combination of 'flagwaving from above and from below' (Eriksen, 2007: 9). If the flags of postcards, performances and the grand-final parade are waved 'from above', fans and the emotional experiences they desire to craft for themselves by waving or wearing a certain flag in the Eurovision arena constitute Eurovision's flag-waving 'from below' - though in between 'above' and 'below' come many different layers of negotiation between the EBU, national delegations, host broadcasters and fan clubs. Eurovision fandoms, and their identity-making practices and discourses, are another major theme of Eurovision research (see, e.g. Singleton, Fricker and Moreo 2007; Kyriakidou et al. 2018). Eurovision organisers are curiously dependent on the fans who constitute their live audience to produce the arena-scale spectacle and the affective charge an audience of cheering fans transmits to broadcast viewers. The broadcast of a live 
crowd event mobilising national (and other forms of collective) sentiment in the manner of an Olympic opening ceremony or major sporting event, Angharad Closs Stephens suggests, invites viewers to share the togetherness of the 'affective atmospheres' of nationalism created in the crowd (Closs Stephens, 2016: 181). It is fans' flag practices in the arena which create the visuality of the atmosphere Eurovision beams into millions of domestic and social spaces, many of which (hosting Eurovision parties) will have been decorated with flag paraphernalia themselves (Sieg 2013b: 24). Though paying attendees, fans in the arena are, through their televised embodied practices, also part of what Eurovision broadcasts and (for advertising and sponsorship purposes) sells. Alongside national flags, Eurovision's large LGBTQ fan base has meant that, since Eurovision expanded into arenas, one of the most visible flags in the audience has been the rainbow flag - pulling Eurovision into the international politics of queer visibility and Pride.

While Eurovision's LGBTQ (especially gay) fandom dates back to the 1970s, Eurovision's on-screen association with queer visibility (see Baker 2017) began in the late 1990s, when its first openly gay contestant (Iceland's Páll Óskar) competed in 1997 and Dana International, an openly trans woman, won for Israel in 1998. The string of contests held in central and east European capital cities in the 2000s, just as many of these countries were going through the EU accession process, brought many rainbow flags inside the arena but created an ongoing Western European fan discourse about whether they could be safely carried outside. Marija Šerifović's heavily queer-coded performance in 2007 symbolically attached a 'utopia of tolerance' to her country, Serbia (Vänskä 2007: 66); at the other end of the emerging spectrum between visibility and repression in global queer politics, when Moscow hosted Eurovision in 2009, the mayor (who had been banning Pride since 2006) sent police to break up a 'Slavic Pride' march on the afternoon of the grand final, leading the BBC commentator Graham Norton to call the contest 'the Beijing Olympics of Eurovision' live on air.

A circuit of controversy about the politics of hosting mega-events in regimes which repressed democratic opposition and sexual dissidence (see Gluhovic 2013) in fact wove between the Olympics and Eurovision from 2008, when Beijing hosted the Olympics and Russia won Eurovision (the reason Moscow hosted in 2009), to 2014, when the passage of Russia's 2013 'gay propaganda' law made Western LGBTQ rights campaigners call for international boycotts of the Sochi Olympics (see Edenborg 2017: 130-1). While the Games were still ongoing, the Russian state provoked foreign diplomatic and public opinion further by sending troops into Eastern Ukraine and annexing Crimea. Many fans and journalists projected a narrative of a 'new Cold War' between Europe and Russia, with (in)tolerance of LGBTQ visibility as one of its defining contested values, on to the Eurovision victory a few months later of the Austrian bearded drag queen Conchita Wurst.

Eurovision's incorporation into the international geopolitics of LGBTQ rights adds an extra dimension to Peter Rehberg's observation, made almost a decade ago, that 'Eurovision provides a rare occasion for simultaneously celebrating both queerness and national identity' (Rehberg 2007: 60, emphasis original). The occasion was rare because, under patriarchal and socially conservative forms of nationalism, queerness and gender variance threaten national 
heteronormative and cisnormative masculinity (Mole 2011): Eurovision, in contrast, let fans celebrate sexuality and nationhood, as well as sexuality and Europeanness, together (see Sieg 2017: 26-7). More such spaces for celebration emerged in the 2000s and 2010s, some even under the auspices of states that had started to perform LGBTQ-friendly national identities (though many queer activists remained cautious of states promoting their LGBTQ-friendliness, arguing states often used it to build a progressive reputation while committing other human rights violations: the term 'pinkwashing' (Schulman 2012: 135), first used in this context by the Palestinian solidarity campaign to criticise the Israeli government's promotional strategies, thus gained wider relevance in global queer politics). The reaction, in Russia and other states where anti-LGBTQ movements and organisations have gained political power, has been for politicians and the Church to further stigmatise queerness and its symbols as contagions imported from the West or (in Russia) so-called 'Gayropa' (Edenborg 2017: 159) - as if 'Europe' is responsible for turning the nation's children gay. The author of Russia's anti-LGBTQ laws, Vitalii Milonov, has indeed pressured Russian broadcasters to leave Eurovision precisely so that sights like Wurst's gender-transgressive appearance would not be transmitted as Russian family viewing (Polyakova 2014: 39). It was against this background that both the politics of unrecognised states and the politics of queer recognition played out in a series of controversies at Eurovision 2015 and 2016 about the display of flags.

\section{Rainbow flags, banned flags and other contentions in Eurovision 2015-16}

The framing of 'Europe' and 'Russia' as two sides in an ideological struggle over LGBTQ rights and visibility, and the notion that Eurovision (where Russia had competed since 1994, becoming one of its most consistent high scorers) was a site where they would inevitably come into contact, led to contention in 2015 when Polina Gagarina represented Russia at Eurovision in Vienna. As the sequel to Conchita Wurst's win in Copenhagen, and the first contest to be without a Ukrainian entry since Ukraine had started competing (Ukraine's broadcaster had not been able to commit financially to Eurovision 2015 because of the Russian-backed war in Donbas), Vienna readily lent itself to 'new Cold War'-style commentary. Indeed, during the grand final where Gagarina led for much of the voting before ending second, the live audience booed so loudly that presenters had to intervene (Hay and Kanafani 2017: 57-9). Gagarina, for her part, was criticised in Russian media by Milonov and others simply for posting an Instagram video of herself giving Wurst a friendly kiss (Schreck 2015), indicating that even as the structuring gaze of Eurovision made her embody the Russian nation (and, for some viewers, its government's policies) to viewers outside Russia, some voices within Russia were rejecting her suitability for embodying that nation at all.

During Gagarina's semi-final a few days earlier, in fact, the disconnect between Russian state homophobia and Russia's participation in a contest with special celebratory meaning to its LGBTQ fans had already been visualised in a manner which did not become so publicly controversial but may have contributed to some struggles over flags the following year. At one moment during Gagarina's performance of 'A Million Voices', the camera had pulled back for one of Eurovision's signature long arena shots and captured her framed by a mass of 
rainbow flags belonging to a group of fans who happened to have brought them to the semifinal. Since Eurovision arenas do not divide different countries' supporters into separate areas, every audience shot in the live broadcast is likely to contain many flags besides those of the country currently on stage, symbolising Eurovision's 'unity in diversity'. The juxtaposition of so many rainbow flags around the Russian entrant, however, produced an accidentally meaningful image for the popular geopolitics of LGBTQ rights: understanding the visual grammar that flags mark places as belonging to the group they stand for, and knowing the context of 'Europe'-Russia relations since 2014, allowed the image to be read as an act of defiance or resistance to homophobia, to Russia, and/or to the cynical intentions some fans had perceived in Russia's record of sending entries about diversity and peace. Its irony did not go unnoticed (Bryan 2015), even though its creation had depended entirely on which flags the audience in those seats happened to have brought: the same moment during the final framed Gagarina with the usual assortment of national flags instead. Viewers' interpretations of and affective reactions to the juxtaposition of the Russian entrant and the rainbow flag exemplified the idea that, in international politics, '[i]mages do not speak for themselves they are made to speak for, by and about us' (Dauphinée 2007: 153, emphasis original) - and at Eurovision 2016 a ticket agency would make images of flags speak even before the contest had begun.

On 28 April 2016, fans with tickets to the Globen Arena in Stockholm were surprised to be sent an 'Official Flags Policy' by SVT's ticketing partner, AXS. Previous ticketers had not issued such detailed instructions, though fans might have expected tighter security measures since Eurovision would be the first politically symbolic arena concert of its kind since the November 2015 Paris attacks had targeted the national football stadium and the Bataclan concert hall. The policy regulated the size of flags and poles which could be brought to the arena, addressing the problem of large flags blocking camera sightlines that had frustrated producers for some years, but became much more controversial when it printed textual and visual lists of 'banned' flags, and called into question certain flags that most fans had not expected would be contentious at all (AXS 2016). The only flags 'allowed', under this policy, were the '[o]fficial national flags' of the countries competing in Eurovision, other recent participants, and other countries provided they were UN member states (AXS 2016: 1). Besides these 'allowed' flags, the text in green also created an ambiguous category of 'tolerated' flags: '[r]ainbow flags and the European Union flag', it stated, 'will be tolerated provided they will, according to the evaluation of the organisers, not be used as [a] tool to intentionally make a political statement during the show' (AXS 2016: 1, emphasis original).

The publication of the 'flags policy' created several exclusions and even more ambiguities which upset a right that fans had until then taken for granted: the right to take a flag expressing their identity into the celebratory space of the live Eurovision audience, and have it take its place among the rest. Causing most outcry was a visual list of nine 'banned flags', amalgamating entities with very different statuses under international law into one category of illegitimacy. The flags shown under the text 'The following flags are specifically not allowed at the Eurovision Song Contest' included those of Kosovo, Nagorno-Karabakh, the Basque 
Country, Islamic State, Crimea (both the Crimean flag used under Russian annexation and the ethnic flag of the Crimean Tatars), Palestine, the People's Republic of Donetsk, Northern Cyprus and Transnistria (AXS 2016: 2, emphasis original). In several cases, the intention appeared to be to prevent unrecognised and de facto states' flags appearing live in countries where those entities were not recognised or their flags could even be against the law.

Yet the organisation of the list equated violent separatist and terrorist movements with countries many UN members had already recognised as sovereign states: Palestine, which had been recognised by the UN as a 'non-member observer state' in 2012 and recognised as a state by Sweden in October 2014 (Eriksson 2018); Kosovo, which had been recognised by 113 countries since unilaterally declaring independence in 2008 and been admitted to the International Olympic Committee in December 2014; and - most embarrassingly, it would turn out - the Basque Country, which has been recognised as an official nationality and Autonomous Community under the Spanish constitution since 1978. No explanation materialised for the Basque Country's inclusion, which appeared to imply the compilers had confused the Basque Autonomous Community's elected government with the Basque terrorist movement that had never governed the Community and had ceased operations in 2011.

The textual list of banned flags also prohibited whole categories of flag that fans had not expected could even be at issue, and created alarming ambiguities for fans who were aware that security guards on the gate would be enforcing the rules. 'Local, regional and provincial flags' were explicitly prohibited, as were 'flags/banners containing and/or representing a statement that the organisers consider of political or religious nature, in particular flags of disputed territories', and (more understandably) those containing 'statements or images that the organisers consider offensive, discriminatory or unsuitable for the public': another line banning flags 'containing statements in another language than English' (even though Eurovision famously has two official languages, English and French) would strictly speaking have prohibited official national flags such as Brazil's, which contains a motto in Portuguese. Sub-state national flags like Wales's and Scotland's also appeared to be banned, since those nations were not themselves UN member states, and (unmentioned) so presumably were ethnic flags such as those of the Sami or Roma. This policy brought Eurovision closer to crowd management at the Olympics, which in London 2012 had banned all flags except those of countries participating in the Games: however, the Eurovision draft policy went further, since London 2012 had at least allowed 'flags of nations under the umbrella of a participating country' and specifically named 'England, Scotland and Wales' (LOCOG 2012: 2).

While the EBU rushed to clarify that the illustrations of banned flags were not EBU policy and had not been intended for publication, and promised that it understood 'the sensitivities of presenting a selection of flags of organisations and territories, each of them of very different nature' (EBU 2016c), outcries in mainstream media centred on national flags which had had their right to recognition undermined by being banned. The portal Wales Online, for instance, headlined its article 'Eurovision puts Welsh dragon on list of banned flags that also includes Islamic State' (Owen 2016). Outrage was greatest in Spain, where the national 
broadcaster Radio-Televisión Española (RTVE) demanded that the EBU remove 'the flag [...] that derives its legitimacy from the Statute of Guernica and the Spanish Constitution itself' from the banned list (RTVE 2016), the government spokesperson Soraya Sáenz de Santamaria promised the foreign ministry would complain to the Swedish government, and even the prime minister Mariano Rajoy appeared to comment indirectly on the scandal by tweeting a pointedly-timed message of support to the Spanish entrant Barei (Fuster 2016). It is likely to have been this pressure, from one of the EBU's 'big five' broadcasters with guaranteed places in the Eurovision grand final and with the backing of the Spanish state, that led to the EBU publishing an updated policy on 1 May with permission for flags to now include 'the language of the host country' as well as English (though not French), and without the illustrated examples of banned flags (EBU 2016a).

As well as its strict approach to what constituted a recognised national flag, the draft policy had also created even more uncertainty over two symbols tightly connected to the 'imagined community' (Sandvoss 2008: 198) that Eurovision broadcasts create: the EU flag and the rainbow flag. Both of these, in the draft policy, were to be 'tolerated' as long as they were not being 'used as [a] tool to intentionally make a political statement' (AXS 2016: 1). 'Tolerance' in queer politics is scarcely full inclusion (see Petschesky 2002), and the rule would have forced security staff to make immediate, arbitrary decisions about fans' intentions, based largely on how they interpreted the appearance and behaviour of those they searched. The EU flag, moreover, has extra politicised meanings in certain countries where (not) belonging to 'Europe' has become an ideological symbol: would an EU flag become political if carried by a British 'Remain' supporter in the then-upcoming EU membership referendum, or a veteran of the Euromaidan revolution in Ukraine? The 1 May policy curtailed the ambiguity around the EU flag by placing it equally to official national flags under a green tick. The rainbow flag was also under the green tick, but unlike the EU flag, continued to be described with hedging language - which both downplayed its meaning as a symbol of LGBTQ identity and protest and avoided the EBU having to commit itself to a stance of allowing a flag with this meaning on screen.

The draft policy's 'tolerance' of the rainbow flag as long as it was not being intentionally used for making political statements conflicted, many queer activists would say, with the flag's history as a collective identity symbol for people whose very right to exist as queer was always politicised already. It played into a depoliticisation of the Pride flag which left-wing and decolonial activists had already come to perceive in the institutionalisation and corporate sponsorship of big-city Prides, the inclusion of police and the military in certain countries into what had originated as a protest against state violence towards queers, and government strategies of 'pinkwashing' (see Bacchetta, El-Tayeb and Haritaworn 2015; Alm and Martinsson 2016; Klapeer and Laskar 2018: 528; Russell 2018). The shared history of resistance and protest that the rainbow flag could symbolise was not officially recognised even in the 1 May policy: this allowed ' $[t]$ he rainbow flag, as a symbol of tolerance and diversity' (EBU 2016a: 1), with no reference to queer identities, sexual minorities or Pride. Meanwhile, the update provided no certainty at all for fans who had questioned whether 
pride flags besides the rainbow flag, with equivalent meaning for their own identity-based community membership, would be allowed.

The flag left most ambiguous under this policy was the blue, pink and white trans flag, which had become more and more prominent in Pride marches and queer demonstrations during the 2010s - not least in protest at cisgender gay and lesbian activists' record of failing to campaign on, or being actively hostile towards, trans interests (see Balzer and Hutta 2014). When asked directly about the trans flag on 1 May, however, the operator of the EBU Twitter account responded simply 'Only flags of participating nations, other UN member states, the rainbow flag and EU flag can be waved @Eurovision this year' (EBU 2016d). Even though Eurovision owed its most iconic performance of the decade to Conchita Wurst (who embodied gender variance through her bearded glamorous appearance, and in 2014's political context had become a symbol of trans visibility), and even though Dana International's victory in 1998 remained a landmark in Eurovision history, the EBU's failure to give guarantees about the trans flag when pressed suggested it did not give trans political subjects the same level of recognition it was prepared to afford to the rainbow flag.

The implications of the EBU not recognising the wider family of pride flags were more than symbolic for fans who, a few weeks before the contest, were already looking forward to travelling to Stockholm, joining in the out-of-the-ordinary space that Eurovision creates in its host cities, and watching the contest live among an international crowd. Alongside the anticipated pleasures of spectatorship in the arena, fans who wanted their presence at Eurovision to feel like an embodied celebration of their trans or bi identity (or another identity with a pride flag of its own) now also had to anticipate something much more intimidating: not knowing whether security would let them into the arena with their flag. Having a flag confiscated would not only mean a financial loss (the policy stated confiscated flags and objects would not be returned), but also losing an object that might well be invested with personal significance from events where the owner had taken or worn it before. Moreover, the policy also permitted staff to remove attendees from the venue for bringing in items that breached the policy: even though this might only have been intended to cover the most extreme cases of offensive behaviour, its wording did not reassure queer and trans fans with painful past memories of being bullied by door staff on nights out that an individual guard would not turn them away for carrying a non-rainbow pride flag (and would not have staved off the potential negative publicity of such an incident being filmed on smartphones and going viral as the contest began). As Eriksen notes, flags matter most the more that the identity they represent is challenged, and the more 'personal emotional resources' have been invested in them (Eriksen, 2007: 10): at a structural level, Eurovision's organisers had not recognised the everyday insecurities of queer and, especially, trans fans.

Despite the extent to which the Eurovision ticketing agency and then its organisers had attempted to regulate fans' display of flags, and the sensitivity this implies there may have been about what flags might end up being broadcast on the transnational live feed, the only serious incident at Eurovision 2016 concerning a disputed flag had nothing to do with fans in the arena - rather, it involved a delegation in the green room. Potential confrontations about 
pride and regional flags at security had not materialised (which is not to say fans' alarm at the possibility had been misplaced), and the EBU had meanwhile relaxed its policy to allow 'national, regional and local' flags of the performers' heritage (including the Welsh and Sami flags) (Duffy 2016) - though again had not taken the opportunity to welcome the trans flag. It seemed flags need not have been a source of anxiety after all. Yet during a reprise of performances in the first semi-final on 10 May, a quick cut to the green room after the Armenian clip captured Armenia's contestant, Iveta Mukuchyan, holding up the flag of Nagorno-Karabakh - the de facto state with an Armenian ethnic majority that is internationally recognised as part of Azerbaijan. The EBU described this as a 'serious breach' of Eurovision rules in a statement the next day, stated that it 'consider[ed] the flag's appearance in the transmission harmful to the Eurovision Song Contest brand', and announced that Armenia would be sanctioned the next Reference Group meeting (which could have led, but did not, to Armenia's disqualification from Eurovision 2017) (EBU 2016b). One of the very flags that the first draft policy had taken most steps to exclude from the arena had appeared on screen, by means that the new rules for fans could have done nothing to prevent.

\section{Conclusion}

Eurovision, with its rituals of competition between nations, exemplifies the paradox of 'unity in diversity' visions of Europe, where celebrating a transnational collective identity involves continued reliance on its component nation-states, while contested and diverse identifications within each nation are often compressed into one undifferentiated national whole. Struggles over national, sub-national and territorial flags can be contentious enough, but still respect a structuring principle of international politics, the link between national selfdetermination and state sovereignty. Eurovision's distinctions about whether or not a flag is political turn, in practice, on whether the entity it denotes has consensus recognition among the international society of states. By deferring decisions on states' legitimacy to the UN, it avoids actively ruling on the legitimacy of territories like Kosovo which some EBU members recognise and others oppose. This pragmatic stance attempts to prevent the EBU itself having to make political decisions. Yet this breaks down as soon as the EBU must rule on flags which do not stand for states or even territorial identities, where no consensus international arbiter exists. Eurovision's compromise, defining the rainbow flag in the broad language of 'tolerance and diversity', does not satisfy activists who insist that queer and LGBTQ identities are political, but prevents confrontation with broadcasters who might come under domestic pressure to object if Eurovision institutionally identified the rainbow flag with LGBTQ Pride. This tension about the visibility of queer symbols and identities echoes a tension that queer people living under state homophobia must themselves negotiate in everyday life (Stella 2015: 128): greater visibility (however much campaigners in the West might struggle for it) often exposes queers to unwelcome attention from wider society and the state (Edenborg 2017: 34-5). Often, in such circumstances, it is safer not to be so visible or so well recognised. 
The very question of whether Eurovision is or should be 'political', in fact, exists in a similar bind. Critical academics may well argue that the field of 'the political' should encompass every form of struggle over how power is distributed or where definitions, identities and representations are contested, since these processes always occur 'within power relations' (Jenkins 2014: 47). Nuclear disarmament, a not uncommon theme at Eurovision, is a subject of political struggle; so are pollution, unemployment, the euro crisis, war commemoration, resilience to terrorism, and the rescue of refugees. Yet if Eurovision rules accepted these themes as 'political', they too might become contentious: there might be more freedom of expression in Eurovision if 'political' remains very narrowly conceived.

Eurovision's recent controversies about the politics of flags expose the limits of determining what is and is not political in contemporary international relations, where nationstates but also movements based on intimate embodied identities seek recognition. Queer sexualities and queer embodiments of gender have become the basis of collective identities and claims for rights - and, more broadly, Cynthia Weber even argues that one of the things that makes power struggles in international politics possible is 'the will to knowledge about sexualities' itself (Weber 2016: 2, emphasis original). Urging International Relations scholars to conceive of a 'queer logic of statecraft', or ways in which subjectivities in international politics can be at once normal and perverse, Weber (2016: 10) organises her argument around an image taken from Eurovision, the embodied persona of Tom Neuwirth as Conchita Wurst. Yet she also emphasises that 'queer International Relations' must stay tied to 'sexes, genders and sexualities' and the bodies which refuse or fail to 'signify monolithically' in heteronormative and cisnormative frames (Weber 2016: 14 citing Sedgwick 1993: 8) - that is, bodies which cannot be kept to one or other side of a binary, which (like Conchita's beard) pose questions without resolving them, and can simultaneously be both normal and perverse.

Flags, with collective meanings and even more personal meanings projected on to them, do not signify monolithically either: indeed, flags' ability to unify people with different understandings of a nation or movement into one crowd is perhaps their very power as a political symbol (Klapeer and Laskar 2018: 531). All flags are polysemic and thus have that ability - but a queer international politics of flags, following Weber, should take particular interest in flags' connections to sexes, genders and sexualities, including flags representing political identities based on these but also flags that appropriate national symbols in queer ways. For movements that turn queer and trans experiences into collective political identities, flags do the same work of symbolising, visualising and mobilising a community as they do for nations (a 'normal' thing for flags to do in international politics) - yet they also claim that other forms of collective belonging should have rights and recognition attached, as well as forms derived from belonging to a nation-state. In Billig's 'world of nations', this claim is more 'perverse'. Without state governments to stand up for them, as the contrasting fortunes of sub-state national flags and pride flags in the 'banned flags' controversy show, their position is structurally much more precarious on the international stage.

\section{References}


Åhäll, Linda. 2018. Feeling everyday IR: embodied, affective, militarising movement as choreography of war. Cooperation and Conflict. doi: 10.1177/0010836718807501.

Ahmed, Sara. 2004. Affective economies. Social Text 22 (2): 117-39.

Alm, Erika, and Lena Martinsson. 2016. The rainbow flag as friction: transnational, imagined communities of belonging among Pakistani LGBTQ activists. Culture Unbound 8 (3): 218-39. http://www.cultureunbound.ep.liu.se/v8/a15/cu16v8a15.pdf. Accessed 1 February 2019.

Ammaturo, Francesca Romana. 2016. Spaces of pride: a visual ethnography of gay pride parades in Italy and the United Kingdom. Social Movement Studies 15 (1): 19-40.

$\begin{array}{llllll}\text { AXS. } & 2016 . & \text { Official flags } & \text { policy. } & 28 & \text { April. }\end{array}$ https://web.archive.org/web/20160428193856/http://cdn3.axs.com/axs/pdfs/FlagPolicyRG.p df. Accessed 1 February 2019.

Bacchetta, Paola, Fatima El-Tayeb and Jin Haritaworn. 2015. Queer of colour formations and translocal spaces in Europe. Environment and Planning D: Society and Space 33 (5): 769-78.

Bajt, Veronika. 2017. The post-communist renegotiation of Slovenian national symbols. Družboslovne rasprave 33 (85): 15-33.

Baker, Catherine. 2008. Wild dances and dying wolves: simulation, essentialization, and national identity at the Eurovision Song Contest. Popular Communication 6 (3): 173-89.

Baker, Catherine. 2017. The 'gay Olympics'?: the Eurovision Song Contest and the politics of LGBT/European belonging. European Journal of International Relations 23 (1): 97-121.

Balzer, Carsten, and Jan Simon Hutta. 2014. Trans networking in the European vortex: between advocacy and grassroots politics. In LGBT activism and the making of Europe: a rainbow Europe?, ed. Phillip M. Ayoub and David Paternotte, 171-92. Basingstoke: Palgrave Macmillan.

Bell, David, and Jon Binnie. 2004. Authenticating queer space: citizenship, urbanism and governance. Urban Studies 41 (9): 1807-20.

Bilić, Bojan. 2016. Europe [heart] gays?: Europeanisation and pride parades in Serbia. In LGBT activism and Europeanisation in the post-Yugoslav space: on the rainbow way to Europe, ed. Bojan Bilić, 117-53. London: Palgrave Macmillan.

Billig, Michael. 1995. Banal nationalism. London: Sage.

Bohlman, Andrea F, and Alexander Rehding. 2013. Doing the European two-step. In Empire of song: Europe and nation in the Eurovision Song Contest, ed. Dafni Tragaki, 281-98. Lanham, MD: Scarecrow Press.

Bohlman, Philip V. 2013. Tempus edax rerum: time and the making of the Eurovision song. In Empire of song: Europe and nation in the Eurovision Song Contest, ed. Dafni Tragaki, 35-56. Lanham, MD: Scarecrow Press.

Bölin, Goran. 2006. Visions of Europe: cultural technologies of nation-states. International Journal of Cultural Studies 9 (2): 189-206.

Bryan, Scott. 2015. Pride flags were caught on camera during Russia's Eurovision performance. Buzzfeed, 19 May. https://www.buzzfeed.com/scottybryan/many-pride-flags-were-caught-oncamera-during-russias-eurovi. Accessed 1 February 2019.

Caspersen, Nina. 2015. The pursuit of international recognition after Kosovo. Global Governance 21 (3): 393-412.

Chinn, Sarah E. 2012. Queer feelings/feeling queer: a conversation with Heather Love about politics, teaching, and the 'dark, tender thrills' of affect. Transformations 22 (2): 124-31.

Closs Stephens, Angharad. 2016. The affective atmospheres of nationalism. Cultural Geographies 23 (2): 181-98. 
Confino, Alon, and Ajay Skaria. 2002. The local life of nationhood. National Identities 4 (1): 7-24.

Dauphinée, Elizabeth. 2007. The politics of the body in pain: reading the ethics of imagery. Security Dialogue 38 (2): 139-55.

Duffy, Nick. 2016. Eurovision reverses flag policy after banning 'political' waving of rainbow flag. Pink News, 9 May. https://www.pinknews.co.uk/2016/05/09/eurovision-reverses-flag-policy-afterbanning-political-waving-of-rainbow-flag/. Accessed 1 February 2019.

EBU. 2016a. Eurovision Song Contest flag policy. https://web.archive.org/web/20160503224920/https://eurovision.tv/upload/2016/ESC2016 f lagpolicy.pdf. Accessed 1 February 2019.

EBU. 2016b. Official statement on use of Nagorno-Karabakh flag at Eurovision Song Contest. Facebook, 11 May. https://www.facebook.com/story.php?story fbid=1045195205572896\&id=226605230765235. Accessed 1 February 2019.

EBU. 2016c. Official statement re publishing of draft flag policy for Eurovision Song Contest. Facebook, 29 April. https://www.facebook.com/EBU.HQ/photos/a.254249654667459/1038141432944940/?type $=3$ \&permPage=1. Accessed 1 February 2019.

EBU. 2016d. @[user] Only flags of participating nations, other UN Member states, the rainbow flag and EU flag can be waved @Eurovision this year. Twitter, 1 May. https://twitter.com/EBU HQ/status/726812600252686337. Accessed 1 February 2019.

EBU. 2019. 'Rules - Eurovision Song Contest Tel Aviv 2019'. https://eurovision.tv/about/rules. Accessed 1 February 2019.

Edenborg, Emil. 2017. Politics of visibility and belonging: from Russia's 'homosexual propaganda' laws to the Ukraine war. London: Routledge.

Eriksen, Thomas Hylland. 2007. Some questions about flags. In Flag, nation and symbolism in Europe and America, ed. Thomas Hylland Eriksen and Richard Jenkins, 1-13. London: Routledge.

Eriksson, Jacob. 2018. Swedish recognition of Palestine: politics, law, and prospects for peace. Global Affairs 4 (1): 39-49.

European Union. 2019. The European flag. EUROPA. https://europa.eu/european-union/abouteu/symbols/flag en. Accessed 1 February 2019.

Fornäs, Johan. 2012. Signifying Europe. Bristol: Intellect.

Fornäs, Johan. 2017. Euro-visions: east European narratives in televised popular music. In Europe faces Europe: narratives from its eastern half, ed. Johan Fornäs, 179-236. Bristol: Intellect.

Fuster, Luis. 2016. Spain: EBU apologizes after Basque flag bans sparks national outrage. Wiwibloggs, 1 May. https://wiwibloggs.com/2016/05/01/basque-flag-ban-political-controversy/. Accessed 1 February 2019.

Gluhovic, Milija. 2013. Sing for democracy: human rights and sexuality discourse in the Eurovision Song Contest. In Performing the 'New' Europe: Identities, Feelings, and Politics in the Eurovision Song Contest, ed. Karen Fricker and Milija Gluhovic, 194-217. Basingstoke: Palgrave Macmillan.

Hart, Maria Teresa. 2017. 4 times Eurovision resisted Putin's anti-LGBTQ stance. Teen Vogue, 9 May. https://www.teenvogue.com/story/4-times-eurovision-resisted-putins-anti-lgbtq-stance. Accessed 1 February 2019.

Hartman, Julie E. 2013. Creating a bisexual display: making bisexuality visible. Journal of Bisexuality 13 (1): 39-62. 
Hay, Chris, and Billy Kanafani. 2017. Boos, tears, sweat and toil: experiencing the 2015 Eurovision Song Contest live. Popular Entertainment Studies 8 (1): 57-73.

Hobsbawm, Eric. 1983. Introduction: inventing traditions. In The invention of tradition, ed. Eric Hobsbawm and Terence Ranger, 1-14. Cambridge: Cambridge University Press.

Hobsbawm, Eric. 1992. Nations and nationalism since 1780: programmes, myth, reality. 2nd ed. Cambridge: Cambridge University Press.

Honciuc, Bogdan. 2017. Exclusive: Portugal's Salvador Sobral says his 'SOS Refugees' sweatshirt is NOT political. Wiwibloggs, 13 May. https://wiwibloggs.com/2017/05/13/ebu-bans-salvador-sobralsos-refugees/. Accessed 1 February 2019.

Jansen, Sue Curry. 2008. Designer nations: neo-liberal nation branding - Brand Estonia. Social Identities 14 (1): 121-42.

Jenkins, Richard. 2014. Social identity. 4th ed. London: Routledge.

Jordan, Paul. 2014. Nation branding: a tool for nationalism? Journal of Baltic Studies 45 (3): 283-303.

Kaelberer, Matthias. 2004. The euro and European identity: symbols, power and the politics of European monetary union. Review of International Studies 30 (2): 161-78.

Kelen, Christopher. 2014. Anthem quality: national songs: a theoretical survey. Bristol: Intellect.

Kestnbaum, Ellyn. 1993. Culture on ice: figure skating and cultural meaning. Middletown, CT: Wesleyan University Press.

Klapeer, Christine M., and Pia Laskar. 2018. Transnational ways of belonging and queer ways of being: exploring transnationalism through the trajectories of the rainbow flag. Identities 25 (5): 52441.

Kolstø, Pål. 2006. National symbols as signs of unity and division. Ethnic and Racial Studies 29 (4): 676701.

Kyriakidou, Maria, Michael Skey, Julie Uldam and Patrick McCurdy. 2018. Media events and cosmopolitan fandom: 'playful nationalism' in the Eurovision Song Contest. International Journal of Cultural Studies 21 (6): 603-18.

Lam, Celia. 2018. Representing (real) Australia: Australia's Eurovision entrants, diversity and Australian identity. Celebrity Studies 9 (1): 117-25.

LOCOG. $2012 . \quad$ Prohibited items.

https://web.archive.org/web/20130402234216/http://www.london2012.com/mm/Document Documents/General/01/25/44/06/Prohibitedandrestricteditemslists Neutral.pdf. Accessed 1 February 2019.

Madison, Nora. 2018. Representing bisexuality in the digital age. In Sex in the digital age, ed. Paul G. Nixon and Isabel K. Düsterhöft, 147-57. London: Routledge.

Mole, Richard C. M. 2011. Nationality and sexuality: homophobic discourse and the 'national threat' in contemporary Latvia. Nations and Nationalism 17 (3): 540-60.

Obućina, Vedran. 2011. A war of myths: creation of the founding myth of Kosovo Albanians. Suvremene teme 4 (1): 30-44.

Owen, Cathy. 2016. Eurovision puts Welsh dragon on list of banned flags that also includes Islamic State. Wales Online, 2 May. https://www.walesonline.co.uk/news/wales-news/eurovisionputs-welsh-dragon-list-11271258. Accessed 1 February 2019.

Petschesky, Rosalind Pollack. 2002. Sexual rights: inventing a concept, mapping an international practice. In Sexual identities, queer politics, ed. Mark Blasius, 118-40. Princeton, NJ: Princeton University Press.

Polyakova, Alina. 2014. Strange bedfellows: Putin and Europe's far right. World Affairs 177 (3): 36-40. 
Ramirez, M. Heliana, and Paul R. Sterzing. 2017. Coming out in camouflage: a queer theory perspective on the strength, resilience, and resistance of lesbian, gay, bisexual, and transgender service members and veterans. Journal of Gay and Lesbian Social Services 29 (1): 68-86.

Raykoff, Ivan. 2007. Camping on the borders of Europe. In A song for Europe: popular music and politics in the Eurovision Song Contest, ed. Ivan Raykoff and Robert Deam Tobin, 1-12. Aldershot: Ashgate.

Rehberg, Peter. 2007. Winning failure: queer nationality at the Eurovision Song Contest. SQS: Journal of Queer Studies in Finland 2: 60-5. https://journal.fi/sqs/article/view/53668/16790. Accessed 1 February 2019.

RTVE. 2016. Eurovisión rectifica tras las explicaciones solicitadas por RTVE y pide disculpas. 29 May. http://www.rtve.es/television/20160429/rtve-pide-se-elimine-ikurrina-entre-banderasprohibidas-eurovision-2016/1347564.shtml. Accessed 1 February 2019.

Russell, Emma K. 2018. Carceral Pride: the fusion of police imagery with LGBTQI rights. Feminist Legal Studies 26 (3): 331-50.

Sabsay, Leticia. 2016. The political imaginary of sexual freedom: subjectivity and power in the new sexual democratic turn. London: Palgrave Macmillan.

Sandvoss, Cornel. 2008. On the couch with Europe: the Eurovision Song Contest, the European Broadcast Union and belonging on the old continent. Popular Communication 6 (3): 190-207.

Saugmann Andersen, Rune, Xavier Guillaume, and Juha A. Vuori. 2016. Flags. In Making things international 2: catalysts and reactions, ed. Mark B. Salter, 137-52. Minneapolis, MN: Minnesota University Press.

Schreck, Carl. 2015. Bearded drag queen grips Russia amid Eurovision fever. RFE/RL, 22 May. https://www.rferl.org/a/conchita-wurst-russia-eurovision-fever/27030576.html. Accessed 1 February 2019.

Schulman, Sarah. 2012. Israel/Palestine and the queer international. Durham, NC: Duke University Press.

Sedgwick, Eve Kosofsky. 1993. Tendencies. Durham, NC: Duke University Press.

Sieg, Katrin. 2013a. Conundrums of post-socialist belonging at the Eurovision Song Contest. In Performing the 'New' Europe: Identities, Feelings, and Politics in the Eurovision Song Contest, ed. Karen Fricker and Milija Gluhovic, 218-37. Basingstoke: Palgrave Macmillan.

Sieg, Katrin. 2013b. Wii are family: performing race in neo-liberal Europe. Theatre Research International 38 (1): 20-33.

Sieg, Katrin. 2017. Imagining European diversity in an age of migration. German Politics and Society 35 (4): 22-45.

Singleton, Brian, Karen Fricker, and Elena Moreo. 2007. Performing the queer network: fans and families at the Eurovision Song Contest. SQS: Journal of Queer Studies in Finland 2: 12-24. https://journal.fi/sqs/article/view/53665. Accessed 1 February 2019.

Smith, Anthony D. 1991. National identity. London: Penguin.

Stella, Francesca. 2015. Lesbian lives in Soviet and post-Soviet Russia: post/socialism and gendered sexualities. London: Palgrave Macmillan.

Strand, Sanna, and Katharina Kehl. 2018. 'A country to fall in love with/in': gender and sexuality in Swedish Armed Forces' marketing campaigns. International Feminist Journal of Politics. doi: 10.1080/14616742.2018.1487772.

Suchland, Jennifer. 2018. The LGBT specter in Russia: refusing queerness, claiming 'whiteness'. Gender, Place and Culture 25 (7): 1073-88. 
Vänskä, Annamari. 2007. Bespectacular and over the top: on the genealogy of lesbian camp. SQS: Journal of Queer Studies in Finland 2: 66-80. https://journal.fi/sqs/article/view/53669/16791. Accessed 1 February 2019.

Vuletic, Dean. 2018. Postwar Europe and the Eurovision Song Contest. London: Bloomsbury Academic. Weber, Cynthia. 2016. Queer International Relations: sovereignty, sexuality and the will to knowledge. Oxford: Oxford University Press.

Yuval-Davis, Nira, and Marcel Stoetzler. 2002. Imagined boundaries and borders: a gendered gaze. European Journal of Women's Studies 9 (3): 329-44. 